\title{
Den patriarkalske Abraham
}

\author{
Professor, dr.theol. \\ Hans Jørgen Lundager Jensen, Aarhus Universitet
}

\begin{abstract}
Behind the well-known "theological” Abraham in Genesis lies the narrative figure that invites an analysis inspired by sociology and anthropology. Abraham is pictured as a wealthy slave- and cattle-owner, competent in negotiation and trade. In matters concerning economy and kinship Abraham is the moderate mediator between violent extremes. In Mary Douglas' Grid/Group scheme, Abraham would be equally remote from priestly-hierarchical and deuteronomistic-enclavist ideals. Underneath the pietistic and ethnocentric themes that the Biblical textual process has added to the figure of Abraham, one can still detect a third position, an alternative to temple-ritualism and to religious zealotry.
\end{abstract}

Keywords: Abraham - Old Testament theology - trade - ritual - Grid/ Group cultural theory - Roy A. Rappaport - Mary Douglas - Victor Turner - Claus Westermann - Bernhard Lang.

Artiklen her vil give et alternativ til de Abraham-billeder i Genesis der normalt er blevet fremhævet i jødisk og kristen tradition. Abraham - troshelten, stamfaderen, offerbringeren - er også velhavende, formentlig engageret $i$ handel, familiefader, og (med Grundtvigs betegnelse), "hedning" (af en slags). Igennem antropologisk og sociologisk inspirerede analyser (Claude Lévi-Strauss, Victor Turner, Mary Douglas, Roy A. Rappaport), der supplerer teologisk-eksegetiske indsigter hos fx Claus Westermann og Bernhard Lang, kan denne alternative Abraham - som jeg vil hævde er den virkelige, gammeltestamentlige Abraham - ses som et alternativ til de dominerende religiøse eller teologiske strømninger i GT, hhv. den præstelige og den deuteronomistiske.

Abraham: teologisk, bibelhistorisk, sociologisk

Den teologiske Abraham kan være en betegnelse på de forestillinger om den bibelske Abraham, som man i nutidens teologiske kontekst og formentlig i den samlede teologiske overleveringstradition - typisk har hæftet sig ved: frem for alt stamfaderen til folket Israel; dertil 
troshelten: Han der "troede Jahve" og fik det regnet til retfærdighed, og pagtspartneren, den der som den første omskar sig selv og de mandlige medlemmer af sit hus på Guds befaling (Gen 15; 17). Hertil hører også den lydige sønneofrer Abraham if. Gen 22. Mens den traditionelt-teologiske Abraham signalerer brud (fra fortid, hedenskab, etniske fællesskaber), ${ }^{1}$ kan en nutidig, teologisk Abraham, med begrebet om "abrahamitiske religioner", indikere mulighed for gensidig forståelighed og fred. ${ }^{2}$ Der er også en bibelhistorisk Abraham, formuleret i fortællinger og billeder med kameler, telte, palmer, bespisning af engle. Her opridses en slags "blød primitivisme" 3 i en underforstået kulturevolutionær model, hvor historien begynder i et nomadisk-eksotisk miljø og en idyllisk familie (enkelte husspektakler til trods). Måske skyldes patriarkhistoriens humane tiltrækningskraft igennem århundreder mere denne idylliske Abraham, med vægt på enkeltpersoner i en familiekontekst, end den mere dystre og strenge, teologiske, Abraham. ${ }^{4}$ Jeg vil her argumentere for eksistensen af en tredje Abraham - som kan kaldes den sociologiske. Der ligger et lille paradoks i, at den teologiske Abraham er langt den mest dramatiske, seriøse og virkningsfulde - men netop derfor også den mest velkendte og i dén forstand den mest konventionelle...

\section{Abraham, rum og tid}

Den teologiske Abrahams træk er dem, som Paulus hæftede sig ved og argumenterede ud fra, jf. Gal 3 og Rom 4: stamfaderen til ikke kun jøder, men også og rettere til de kristne, omskærelsen som tegn på den gamle pagt, troen på Kristus, ikke på loven som adgang til forløsning. Denne Abraham er velkendt i den eksegetisk-teologiske

1. Et brud der kan fungere som indeks for en totalitær autoritetstro med potentiale for terrorisme: Troels Nørager, Taking Leave of Abraham (Aarhus: Aarhus Universitetsforlag 2008).

2. Kategorien "abrahamitiske religioner" er givetvis primært relevant for "religionsdialog"; en generel kritik af begrebets relevans: Peter Sloterdijk, Im Schatten des Sinai (Berlin: Suhrkamp 2013), 48 (et "post-antisemitisk fantombegreb”); en kristen-teologisk protest: Adam Dodds, "The Abrahamic Faiths? Continuity and Discontinuity in Christian and Islamic Doctrine”, Evangelical Quarterly 81 (2009), 230-253.

3. Arthur O. Lovejoy \& George Boas skelnede i deres kortlægning af græske, mytologiske forestillinger nyttigt imellem "soft primitivism" og "hard primitivism" i Primitivism and Related Ideas in Antiquity (1936), (Baltimore: The Johns Hopkins University Press 1997).

4. Jf. Bernhard Lang; The Hebrew God. Portrait of an Ancient Deity (New Haven: Yale University Press 2002), 183. 
litteratur. Det samme kan ikke siges om den sociologiske Abraham. I en tidligere artikel ${ }^{5}$ har jeg hævdet, at Genesis' Abraham repræsenterer en form for religiøsitet eller mentalitet der står i kontrast til de dominerende strømninger i gammeltestamentlig religion (eller "teologi", om man vil), den deuteronomistiske og den præstelige. Denne Abraham er beslægtet med stemningen i den gammeltestamentlige visdomslitteratur, navnlig Ordsprogenes Bog, hvor al interesse samler sig om det sociale: forholdet mellem forældre og børn, ægtefæller, mennesker i overskuelige, lokale sammenhænge. ${ }^{6}$ Ironisk nok er visdomslitteraturen netop ved at fokusere på de nære, "sub-nationale", relationer også tættere på det internationale - visdommen springer så at sige det nationale og regionale over. Privatpersonen Abraham "har" nok et sted - et sted at slå sig ned som fx i Mamre ved Hebron - men ikke et udstrakt territorium der er "hans" og hvor han eller hans guddom bestemmer reglerne; i stedet interagerer Abraham konstant med ikke-israelitter. Visdomsagtigt er også det uproblematiske fravær af netop alt, hvad der er centralt i de dominerende, teologiske diskurser: både præstelige regler for helligt og profant, præster og lægfolk, hvem der må være hvor og røre ved hvad, osv., og deuteronomistiske tyngdepunkter som folket, nationen, byen, militant monolatri osv. I den nævnte artikel fremhævede jeg også, at Abraham-fortællingerne gennemgående præsenterer ham som meget rig, og at Abraham gennemgående konfronteres med aktører med stærke viljer og potentiel destruktiv magt: jordiske konger, stormandsforsamling, fjerne slægtninge, guddommen Jahve (og hans egen kone). I alle tilfælde er Abraham en smidig, empatisk forhandler som accepterer forhandlingssituationens koder og regler. Også heri ligger en ikke-, og formentlig anti-, deuteronomiserende tendens.

Den afgrænsning fra andre grupper som er grundtendensen i den deuteronomistiske tænkning, indebærer en "kompleksitetsreduktion" hvad angår kommunikativ og social handlen. Hvorfor bruge energi på at kende andre menneskers adfærdsnormer eller at rekonstruere hvad andre måtte tænke om eller forvente af én hvis man ikke har noget med dem at gøre? Omvendt er der én bestemt profession som i særlig grad aktiverer de abrahamske egenskaber: Det er den handlende, "stor-købmanden" om man vil - den der udveksler varer og

5. Hans J. Lundager Jensen, ”Abraham, høflighedens ridder”, DTT 74 (2011), 3-21. 6. Jf. min artikel "Visdom" i Gads Bibel Leksikon (København: Gad 1998), 881f. Det giver altså god mening, at visdommens emblematiske repræsentant i GT er netop kong Salomo, med de vidtstrakte internationale forbindelser (1 Kong 5; 10). Ved at være klog på dyr og planter (jf. "fra cedertræet på Libanon til oreganoen ['isoppen'], der vokser ud fra muren”) var han klog på de ting der var fælles for israelitter og deres naboer. 
værdier på et marked med mennesker, som ikke tilhører den handlendes egen familie eller etniske gruppe. Dette er hvad Abraham gør, eller hvad der må være underforstået som kilden til hans store rigdom. Abraham fremstilles ikke som $\mathrm{fx}$ mineejer eller røverhøvding. Uden tvivl har han (og hans nevø Lot) haft en solid kapital med sig hjemmefra ved udvandringen til Kana'an; Gen 12,4 tyder mere på forudgående handelsaktivitet end på passiv overførsel af tidligere generationers akkumulerede værdier i form af arv ("al den rigdom, de havde samlet, og alle de folk, de havde skaffet sig i Karan”). Men selv om det forbliver ubestemt, hvorfra rigdommen kommer, får man dog et hint. Rigdommen er erhvervet i Karan (חרן), altså i en by hvis akkadiske navn viser hvad den var til for: harrānu = vej, (forretnings-) rejse, karavane. ${ }^{8}$ Abrahams urbane baggrund (fremhævet af "P-kildens" tilbagedateringen af slægten til netop den urgamle by Ur; Gen 11,28. 31) udelukker i øvrigt ikke hverken agerbrug eller husdyrhold som hel eller delvis årsag. Lot slår sig ned i en by - uheldigvis for ham Sodoma (Gen 13,12f.). Vi får ikke at vide, hvad han lavede dér. Men man kan nok udelukke en karriere som byskriver, officer eller præst; realistisk er kun en form for håndværk eller handelsvirksomhed, begge dele suppleret med bynært agerbrug. Lots rigdom (Gen 13,5f.) udelukker at han måtte slå sig igennem som daglejer eller lign. ${ }^{9}$ I Gen 19 præsenteres Lot ikke som proletar eller slave, men som husejer med materielle muligheder for at leve op til gæstfrihedskonventioner. At leve som fremmed ${ }^{10}$ med en solid kapital i ryggen vil nok sige at etablere sig som lokalt residerende handelsmand af fremmed herkomst en ikke ukendt type i GT (jf. 1 Kong 20,34; Neh 13,16). ${ }^{11}$

7. I det underlige kap. 14 om Abraham som feltherre opnår han ganske vist et stort bytte; men det gives tilbage til de oprindelige ejere (v. 16).

8. A Concise Dictionary of Akkadian (Wiesbaden: Harrassowitz 2000), s.v.

9. If. R. de Vaux, Les institutions de l'Ancien Testament (Paris: Cerf 1976), 117, var flertallet af gerîm sammenlignelige med perioiker i Sparta, fattige fremmede fastboende; men de kunne komme til penge: Lev 25,47; Deut 28,43.

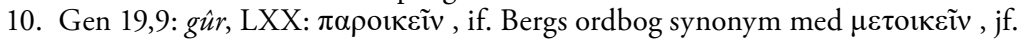
metoikerne, tilflytterne i oldtidens Athen; og jf. R. Martin-Achard, in: Theologisches Handwörterbuch zum Alten Testament (München: Chr. Kaiser Verlag 1971), 410.

11. Der er formentlig generelt en "by-glemsel" og "handels-glemsel" i det gammeltestamentlige fag. Bybaseret handel ignoreres $\mathrm{fx}$ i Victor Matthews \& Don C. Benjamin, Social World of Ancient Israel 1250-587 BCE (Peabody, Mass.: Hendrickson 1993) og i Erhard Gerstenbergers ellers sociologisk baserede Theologien im Alten Testament (Stuttgart: Kohlhammer 2001). Byers funktion som handelsknudepunkter overses i artiklen "Stadt" i Crüsemann et al., Sozialgeschichtliches Wörterbuch zur Bibel (Gütersloh: Gütersloher Verlagshaus 2009); artiklen "Handel” sammesteds kommer ikke ind på en mulig "handelstandens sociologi" el. lign. Karakteristisk nok kan Matthews \& Benjamin ikke se andet i Lot end en kvægnomade. 
Hvis man kan tage Sodoma som et indbegreb af fænomenet by (givetvis: når den er værst), vil adskillelsen mellem Abraham og Lot ang. valget af rum at leve $i$ have en social dimension: Lot vælger at bo i en by, Abraham vælger at forblive udenfor. Men Abrahams livsrum er ikke en flugt fra alt, hvad der måtte konnotere bymæssighed. Han slår sig ikke som en Elias ned i ørkenagtig ensomhed (1 Kong 17,5). Tværtimod; efter at have passeret Sikem - der vel må tænkes som en by (Gen 33,18) - slår Abraham sig foreløbig ned imellem Betel og $\mathrm{Aj}$ $(12,8)$. Mamres Ege ligger givetvis i et åbent, pastoralt land, men

\begin{tabular}{|l|l|}
\hline \multicolumn{2}{|c|}{$\begin{array}{l}\text { Abraham: landet } \\
\text { mellem by og ørken }\end{array}$} \\
$\begin{array}{l}\text { Lot: by } \\
\text { dekadent }\end{array}$ \\
\end{tabular}
i fodvandringsafstand af Sodoma $(18,22)$; og familiegravstedet skal absolut ligge på de byboende "hittitters" område, i forhold til hvem Abraham (som Lot) er en fremmed $(23,4)$. Ganske vist dominerer kvæghold som økonomisk livsform i Abrahamfortællingerne - baggrunden for den mere bibelskhistorisk prægede "nomade"-forestilling, der modsiges af Abrahams hornkvæg $(15,9 ; 18,7)$, der indikerer en mere fastboende livsform. ${ }^{12}$ Kornprodukter, der som en selvfølgelighed indgår i husholdningen (18,6; 21,14), kan selvfølgelig tænkes erhvervet ved bytte med animalske produkter. Men omvendt kan Abrahams store hushold af trælle nok bedre forstås som markarbejdere? Under alle omstændigheder ligger forestillingen om ejerskab af jord og fast bopæl ikke uden for Abrahams horisont, som det fremgår af kap. 23. Her foregår forhandlingerne om overtagelse af grunden udpræget urbant i byporten $(23,10)$.

I alt dette beskrives Abraham som en figur i seræn afstand mellem land og by: ikke for tæt på som Lot, der med nød og næppe reddes ud af sit nyfundne sted, ikke så langt væk som sønnen Ismael, der kommer til at leve i en ørken som bueskytte $(21,21)$ med en egyptisk kvinde. Uanset hvad der nærmere ligger i dette - måske jæger (i lighed med den fremtidige Esau) $?^{13}$ - vil denne profession næppe være

12. Jf. Ernst Axel Knauf, Die Umwelt des Alten Testaments (Stuttgart: Katholisches Bibelwerk 1994), 60.

13. Kommentarlitteraturen (fx August Dillmann, Die Genesis [Leipzig: S. Hirzel ${ }^{6} 1892$ ], 287; Hermann Gunkel, Genesis (1910) [Göttingen: Vandenhoeck \& Ruprecht ${ }^{3} 1969$ ], 231) har set bueskydningen som etnisk-kulturel indikation (ismaelitiske stammer, beduinliv); Gerhard von Rad, Genesis, (Alte Testament Deutsch, Göttingen: Vandenhoeck \& Ruprecht, $\left.{ }^{10} 1976\right)$, 185 så buen som metonym for jagt og rov, $d v s$. (!) som et liv som kamelnomade, beduin. 
indbegrebet af social fremkommelighed. Abraham eksemplificerer en mellemposition imellem den overfyldte by - der efter borgernes natlige adfærd at dømme udmærket lader sig beskrive som en "erototop" med et dystert misundelsesfluidum (Gen 19,4-9) ${ }^{14}$ - og den tomme ørken hvor andre levevæsener ideelt set indskrænker sig til byttedyr (og måske en forsvarsløs rejsende). Ismaels bue er "første og næsten eneste gang” der nævnes et våben i Genesis (Westermann 1983, 420). Dermed er også antydet at Abraham står som en fredens position imellem to typer af voldelighed.

\section{Abraham: fader, ægtemand, broder, onkel}

Det stående spørgsmål om det rette forhold mellem det for fjerne og det for nære er også til stede i notitsen om Ismaels (eksogame) ægteskab med en egyptisk kvinde selv om den dominerende kode her ikke er økonomi, men slægtskab. Men ægteskabsproblematikken dukker ikke ligefremt uforberedt op. Teksterne spilder jo ingen ord på at beskrive hovedpersonerne, fx træk ved deres udseende eller deres klædedragt. ${ }^{15}$ Magtpåliggende er derimod præcisering af familieforholdene: hvem der er far til hvem, og hvem der er gift med hvem (11,27-32). Der er tilsyneladende kun én interessant ting at fortælle om Lot: at han er Abrahams patrilaterale nevø. (De P-agtige tekster excellerer desuden i angivelser af alder: Tera blev 205 år gammel; Abraham var 75 år gammel, da han forlod Karan, osv.).

Abrahams hustru, Sara, har en dobbelt funktion. Den første er at inkarnere en for nær position: Hun er nok hustru, men også søster, dog ikke hel-, men kun halvsøster $(20,12)$. At dette ligger faretruende nær en incestuøs relation, bekræftes som bekendt af Gen 20 der - givetvis med rette (i standardkommentarerne) ${ }^{16}$ - ses som en moralsk aflastning af, hvad der kunne se ud som en løgn i fortællingen om farao og Sara i kap. 12. Men den moralske korrektion sker igennem den kode, som skabte problemet, og den føjer sig logisk ind i de relationer der i øvrigt tematiseres. Den uundgåelige incestproblematik (i det mindste logisk set) efter Edens Have og efter Syndfloden er

14. Et grundtræk ved menneskelige fællesskabsdannelser: Peter Sloterdijk, Sphären III: Schäume (Frankfurt am Main: Suhrkamp 2004), 405-411.

15. Selvfølgeligt gennemgående for GT; men der dukker dog lejlighedsvis små informationsstumper op: udseende: David (1 Sam 16,12); Daniel (Dan 1,4); påklædning: Aron (Ex 28); Elias (2 Kong 1,8).

16. Fx J. Alberto Soggin, Das Buch Genesis (Darmstadt: Wissenschaftliche Buchgesellschaft 1997), 295. 
ganske vist delvis underspillet i Genesis. Men motivets opdukken i patriarkfortællingerne (Lots døtre: 19,31-38; Ruben og Bilha: 35,22; Juda og Tamar: kap. 38) viser at spørgsmålet ikke lå uden for den "israelitisk"-kulturelle forestillingshorisont. Dels har incestforbud en kvasi-universel udbredelse i alle samfundstyper, dels er der eksplicitte forbud herimod i Lev 18 og 20. Incest har udgjort et modstykke til den mere eksplicit tematiserede, inverse problemstilling: eksogamiet, dvs. det problem at de umiddelbart mest nærliggende ægteskabsforbindelser - "kvinderne her i landet" (Gen 27,46) - bedømmes som utilladeligt fjerne. Dette tema breder sig i fortællingerne om generationerne efter Abraham, selv om teksterne ikke umiddelbart synes at have en konsistent holdning til sagen. Esaus ægteskaber med "hittitterinder" fordømmes entydigt. Dinas mulige æoteskab med kana'anæeren Sikem forhindres blodigt af hendes brødre Simeon og Levi, mens fortællerstemmens holdning her er mindre klar (Gen 36). Judas ægteskab med en datter af kana'anæeren Shua har dramatiske konsekvenser, men fordømmes ikke i sig selv (Gen 38). Josefs ægteskab med Asenat, datter af præsten Potifera fra Heliopolis, noteres uden moraliseringer; ligeså med Josefs egyptiske navn, Safenat-Panea. At svigerfader og datter i øvrigt har haft egyptiske guder som patroner - deres nav-

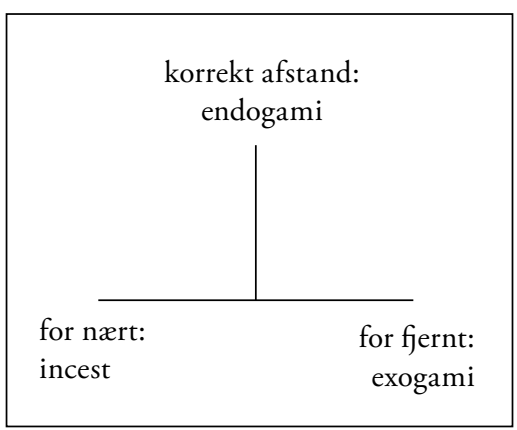
ne indeholder hhv. Re og gudinden Neith - udløser ikke fordømmelser.

Forbuddet imod incest tages for givet i Genesis - det fortælleværdige ved Abraham er just at han går til eller lige over grænsen - og det tvinger fortællingerne ud i de logiske operationer imellem det for nære og det for fjerne og det besværlige spil imellem en gensidig, ordentligt handel (Abraham - til opbyggelse) og udveksling af bedrageri og trickery (Jakob - til skadefryd og underholdning), som udgør substansen i så stor en del af patriarkfortællingerne.

Genesis' fokusering på slægtskab skyldes formentlig, at dette er en særligt fremtrædende og nærliggende måde, hvorpå socialitet som sådan kan tænkes. If. Lévi-Strauss kunne familier ikke være mindsteenheder i menneskelige samfund. Selv om familier i princippet kan reproducere sig selv materielt (i jæger-samler- og i tidligt-agerbrugs-samfund), kan de det ikke kropsligt uden enten at begå incest eller indgå aftaler med andre familier om at udveksle medlemmer (typisk kvinder). Da alle samfund har kendt regler imod incest, må 
mindsteenheden i et samfunds sociale struktur - "atomet" - være en struktur, der omfatter mindst to familier. ${ }^{17} \mathrm{Ud}$ over de relationer i en familie man umiddelbart forbinder med den: ægteskab, blodsbeslægtethed og afstamning, må der derfor indgå en udvekslingsrelation, en "alliance". Til en familie hører altså en giver udefra - enklest i form af en hustrus fader eller broder. I en af de enkleste og hyppigste versioner er den eksemplariske alliancepartner moders broder, dvs. ægtemands svoger, der indgår i en særlig "avunkulær" 18 relation til ægteparrets børn. Denne struktur er if. Lévi-Strauss "slægtskabsatomet". ${ }^{19}$ If. den implicitte logik forhindres dermed en rent biologisk orden; hver gang en ny familie skal dannes, træder samfundet til. Genesis der ikke mindst handler om begyndelser, tematiserer forholdet direkte i og med Lots døtre i hulen efter ødelæggelsen (Gen 19,29-38). Mere problematisk er Abrahams tilfælde; også her skal der begyndes forfra, men uden at fortællingerne vil betale den logiske pris med fortællinger om egentlig incest. Til gengæld kan den sociologiske Abrahams karakter udfolde sig.

\section{Ægteskab, handel}

Mens Ismaels ægteskab sker uden Abrahams medvirken, bliver Rebekka Isaks hustru igennem omstændelige forhandlinger mellem Abrahams stedfortræder og kvindegiveren, Rebekkas broder Laban (Gen 24). Her fremhæves det ligefrem at ægteskabsudveksling er udveksling: Abraham giver Laban "kostbare gaver" (v. 53). Og så er der samtidig tale om en eksklusiv udgave af en handel. Den foregår ikke imellem i princippet vilkårlige partnere som på et marked for almindelige varer, men imellem medlemmer af samme slægt, og de værdier der fremhæves mest - guldringe til næse og arme, sølvsmykker, guldsmykker og klæder (v. 22. 53) - går til Rebekka selv, ikke til hendes familie. Tilmed sker "handlen' under udførelse af store retoriske og også gestikulerende (v. 52) udtryk. Tilsvarende i kap. 21, hvor

17. Claude Lévi-Strauss, "The Family", Man, Culture, and Society, red. Harry L. Shapiro (New York: Oxford University Press 1965), 261-285 , 277f.. Logikken kræver at familier der modtager, også selv giver; men dette er et akut problem i patriarkfortællingerne: jf. Hans J. Lundager Jensen, Den forterende ild (Aarhus: Aarhus Universitetsforlag 2000, 495-497.

18. avunculus: morbror; "onkelagtig'.

19. If. også Robert A. Oden Jr., The Bible Without Theology (Urbana: University of Illinois Press 2000); men her ses bort fra den økonomiske dimension. - Oden fremhæver det typiske avunkulære forhold imellem Laban og Jakob; noget lignende, men i delvis invers udgave, kan ses imellem Abraham og Lot. 
Abraham sikrer sig rettigheden til en brønd. Det kunne her blot dreje sig om en handel eller en slags leje-aftale, hvor Abraham køber sig brugsretten til brønden ved at betale "nogle får og køer" samt syv lam (v. 27-30). Men handlen er vævet ind i et allerede etableret forhold, og de syv lam er en ydelse efter aftalens indgåelse, der ligger i et uklart grænsefelt mellem bytte og gave. Det "rene ægteskab" og den "rene handel", tilhørende separate "værdisfærer", ${ }^{20}$ ville her tydeligvis være anakronismer i forhold til en israelitisk, dvs. "traditionel", endnu-ikke-uddifferentieret samfundsorden, hvor økonomi og socialitet ikke kan tænkes eller praktiseres uafhængigt af hinanden.

Tilsvarende indtryk får man af fortællingen om købet af gravstedet i Gen 23. Byttet af værdier - grundstykket imod 400 sekel - er indlejret i udveksling af høfligheder, som viser at, bekymring om eller omsorg for social status og gensidig anerkendelse formentlig er vigtigere for de involverede end handlen selv. Abraham vises som en kompetent behersker af handlens spilleregler, dvs. af regler han ikke selv har etableret. ${ }^{21}$ Abrahams husstand udgør i princippet et miniunivers, en "immunsfære", ${ }^{22}$ hvis ideal er at forblive uforstyrret i sin aflukkethed; det gennemgående ønske er at være på passende afstand af andre tilsvarende sfærer, jf. adskillelsen mellem Abraham og Lot i kap. 13 og Abimeleks og hærføreren Pikols afrejse fra Be'ersheba i kap 21. Men Abraham kan ikke undgå at komme i berøring med en større og mere magtfuld, ikke-israelitisk omverden, der har værdier, som kun kan erhverves ved et bytte. Og her er det nødvendigt at acceptere ikke-israelitiske normer, dvs. at kunne neutralisere sin egensfæres styring af sine handlinger. ${ }^{23}$ "Israelitiskhed" i Abrahamfortæl-

20. For at tale med Max Weber. Et attraktivt alternativ, hhv. supplement, ville være med Peter Sloterdijk (2004), 74-76 et passim, at tale om "ekspliciteringer": sondringen imellem ægteskab og handel bliver klar når de er blevet separeret i den sociale praksis (som forholdet mellem sex og forplantning i nutiden).

21. Heri en indlysende forbindelse imellem ritual og handel: Roy A. Rappaport, Religion in the Making of Humanity (Cambridge: Cambridge University Press) 1999, 24, definerede ritual som "the performance of more or less invariant sequences of formal acts and utterances not entirely encoded by the performers". - I øvrigt er der endnu tættere relationer: Durkheims forskel mellem den agiterede, effervescente "hellige' forsamling og isolationen af individer i profane dagligdagsrutiner. Se Émile Durkheim, Formes élémentaires de la vie religieuse (1912) (Paris: PUF 1994), 307 lader sig nemt overføre til forholdet mellem markedsplads og arbejdsrum.

22. Sloterdijk (2004), 192-207. I lighed med biologiske organismer som fx menneskekroppe kan også menneskelige super-strukturer (samfund, kulturer) med fordel betragtes som selvopretholdende og selvproducerende systemer med reaktions- og forsvarsmekanismer i forhold til stressfaktorer fra deres omgivelser.

23. Hvilket var selve definitionen af det humane hos Durkheim (1994), 295f.: evnen til at lade sig bestemme af en kollektiv vilje ("hvert øjeblik må vi underkaste os regler for adfærd og tænkning som vi hverken har skabt eller villet og som under- 
lingerne har altså sine grænser. I virkeligheden adskiller Abraham sig ganske lidt fra sine omgivelser. Ud over hvad der eksplicit fremhæves i fortællingerne er der tillige et usagt fællesskab mellem Abraham og andre, ikke-proto-israelitiske mennesker: I alle tilfælde tales der samme sprog; ingen steder hører vi om behov for en tolk. Men sprog i Genesis' verden omfatter ikke kun ord, men også gestik, ting (væddere, næseringe) og retorik. Sådanne "indeksikale" tegn ${ }^{24}$ formulerer betydning på en langt mindre præcis måde end fx talte ord; til gengæld kan de have større kommunikativ effekt: Abraham anerkender hittitternes status tydeligere ved at kaste sig ned end ved at formulere det med mange ord. I begge tilfælde ville der være tale om fraser. Men mens det talte sprog er let, er kroppen tung; "vægtige ord" er ikke kun en talemåde. Abraham er den indeksikale kommunikations mester.

\section{Handel, initiation, politik}

Ægteskabsudveksling og handel er altså i Genesis ikke isolerede felter, men to positioner i en kontinuert sfære, defineret af bytte af værdier. Adgang til denne sfære forudsætter to besiddelser: dels værdier (jf. Abrahams fremhævede rigdom), som man er villig til at afgive, dels kommunikativ kompetence. I denne sfære mødes partnere, hver med sine potentielt afgivelige værdier og hver med sit bestemte begær: Abraham begærer en brønd, et gravsted, en svigerdatter, og han afgiver gerne kvæg, penge, guldsmykker. Partnerne udveksler værdier og, sikkert lige så vigtigt, anerkendelses-meddelelser, og de forlader hinanden igen. Familiesfæren lukker sig atter sammen om sig selv. Handlen som proces kunne sikkert generelt - og kan oplagt i Genesis - analyseres som en slags initiationsritual med overgangsritualets klassiske tre faser: separation, liminalitet, aggregation: at forlade sin familiesfære, at engagere sig i en i princippet risikofyldt "anden verden" uden for sin familie-sfære, og at vende tilbage til den trygge sfære igen, nu i en mere eller mindre forandret tilstand. If. Victor

tiden står i modsætning til vore mest fundamentale tilbøjeligheder og instinkter”). I Abrahamfortællingerne er det åg Abraham må underkaste sig, ikke Jahves vilje, men en ubestemt og ubenævnt, social-kulturel "ethos' (jf. Clifford Geertz, The Interpretation of Cultures [New York: Basic Books 1973], 89f.), der forbinder protoisraeliter med andre.

24. Jf. Rappaport (1999), 54-58. Indeksikale tegn har betydning ikke ved en social overenskomst (som "symboler", dvs. arbitrært-konventionelle tegn så som de fleste ord), men ved en naturlig kontinuitet mellem tegn og betydning. 
Turner er den liminale fase som bekendt typisk markeret dels med initiandens eller symboliserede opløsning ("ikke længere levende", "endnu ikke født"), dels med konfrontationen med det ukendt-monstrøse (vrængbilleder og bizariteter). ${ }^{25} \mathrm{Og}$ selv om oplevelsen af mødet med det mandlige borgerskab i Hebron eller slægten i Karan just ikke går så langt som til Abrahams (hhv. hans udsendings) symbolske

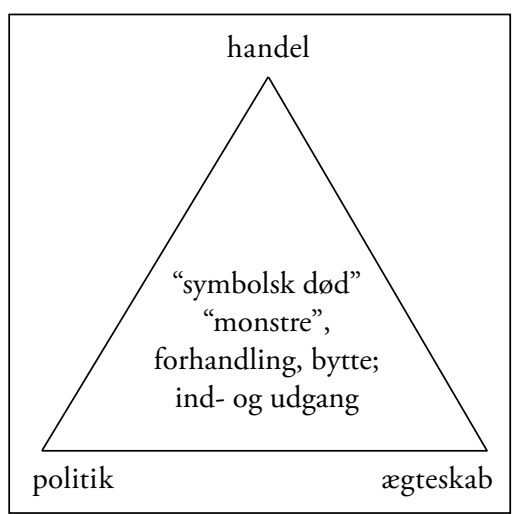
kropslige opløsning, vil det ikke være for vidtgående at se trangen til at kaste sig til jorden (Gen 23,7 12.; 24,52) ${ }^{26}$ som en, indrømmet stærkt afsvækket, form for symbolsk død, eller byttepartneren som et, igen indrømmet stærkt afsvækket, "monster", som ikke er én selv og som dog mærkeligt ligner på mange måder.

I initiationsritualet er det ikke kun vigtigt at komme ind - ellers ingen ændring af status - men også at komme ud igen - ellers ingen relevans af den ændrede status. ${ }^{27} \mathrm{Og}$ selv om handelspartnerne ikke som ritualets monstre truer med at fortære initianden / den handlende israelit, så antydes dog i Genesis den principielle risiko for at blive slugt op. Abrahams træl har travlt med at komme hjem igen efter velgennemført udveksling (24,54-59). Og ét motiv blandt flere for Abraham til at afvise hittitterens høflige karakteristik af ham som en "Guds stormand iblandt os" $(23,6)$ og altså insistere på sin egenkarakteristik som "fremmed og tilflytter" (v. 4) kunne godt tænkes at være at undgå at forholdet bliver for hjerteligt - nevøen Lots eksempel viser jo både, at dette er en problemstilling, der er direkte tematiseret i Abrahamfortællingerne, og hvor galt det kan gå for den, der kommer for tæt på.

Abrahamfortællingernes Abraham er således den gennemførte mediator, en formidler og forhandler hvormed mødet med de andre og med det andet tematiseres og eksemplificeres - som vi har set udfol-

25. Victor Turner, The Forest of Symbols (Ithaca: Cornell University Press 1967), 96. $103 \mathrm{f}$.

26. Proskynese var en indøvet gestus i GTs nærorientalske kontekst, jf. kong Jehus proskynese for den assyriske konge på den berømte "sorte obelisk", og de vestesemitiske småfyrster i midten af 1300-tallet f.Kr., der if. deres breve (Amarna-brevene) rullede sig rundt i støvet syv gange for den egyptiske hersker.

27. Bortset fra de initiationsritualer hvor initianderne etablerer sig i en form for permanent liminalitet, et varigt "communitas": Victor Turner, The Ritual Process. Structure and Anti-Structure (Ithaca: Cornell University Press 1969), 131-165. 
det i de økonomiske og slægtskabsmæssige koder. Overalt kommer Abraham ud af disse møder på fredelig vis; han bevarer sin individualitet og sin afstand til de andre, uden at skulle bruge magt, uden at fornærme, uden affekt. En tredje kode i Abrahamfortællingerne, der føjer sig til den økonomiske og den slægtskabsmæssige, er den politiske. Den skal ikke tages op til en nøjere analyse her; men den hænger sammen med ægteskab og handel, som det fremgår af at Abraham igennem den politiske hersker farao bliver rig af at have udgivet Sara for sin søster (Gen 12; 20) og af den allerede kommenterede "handel' med brønd for kvæg med den lokale store mand i kap. 21. Her, mere end i de andre felter, er truslen om mødets "monstrøsitet" indlysende. Mens Abrahams træl trods alt kun risikerer at blive opholdt unødigt i Nakors by en halv snes dage (men Jakob sad fast i 14 år), frygter Abraham at blive dræbt i Egypten og i Gerar (Gen 12,13; 20,11). Og Abimelek havde militær backup da han sluttede brønd-aftalen med Abraham.

\section{Abraham og "Grid/Group cultural theory'}

Så langt har vi set på Abrahamfiguren som brik i økonomiske og slægtskabsmæssige relationer. Formålet har som sagt været en udvi-

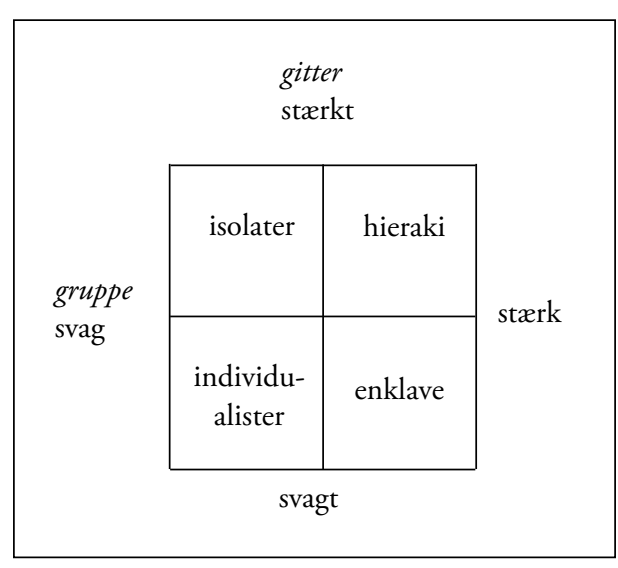

model for organiseringer af forholdet mellem samfund og individ, der skyldes den britiske "symbolske" antropolog og afrikanist Mary Douglas der i øvrigt selv har forsket i GT. Modellen, der er velkendt i sociologiske sammenhænge, kaldes "grid / group cultural theory". Den er blevet opstillet i flere versioner med delvis skiftende definitio- 
ner. Her holder jeg mig til den version, Douglas har beskrevet i sammenhæng med hendes analyse af forskellige syn i Numeri på hvad den sociale størrelse "Israel" bør være. ${ }^{28}$

Douglas antager, at man kan skelne mellem grundlæggende fire måder, hvorpå samfund kan organisere sig, bestemt af to sæt af modsætninger: dels forholdet imellem individ og kollektiv, dels forholdet individerne imellem (forholdet mellem en høj og en lav grad af forudbestemte roller). Den første modsætning betegnes med "group", altså mulighed for stærk eller svag gruppe: styrke vil her sige graden af den magt en gruppe kan have over dets individer. Den anden modsætning betegnes med det engelske "grid", dvs. "gitter" ${ }^{29}$ der tilsvarende kan være stærkt eller svagt. Individer kan være fastholdt i stærke gitre, både hvor gruppe-aspektet også er stærkt (som fx i religiøse hierarkier) og hvor det i øvrigt er svagt ( $\mathrm{fx}$, som et ekstremt tilfælde, i forholdet imellem eneboere). De to positioner med stærkt gruppeaspekt benævner Douglas hhv. hierarki og enklave; de adskiller sig ved hhv. et stærkt og et svagt gitter. For de konstellationers vedkommende hvor gruppeaspektet er svagt, taler Douglas om hhv. samfund af isolater (svag gruppe og stærkt gitter) og samfund af individualister (svag gruppe og svagt gitter).

Alle grupper besidder både udvendige og indvendige afgrænsninger, altså både grænser imellem gruppen selv og dens omverden og afgrænsninger imellem gruppens medlemmer. Forskellen imellem hierarki og enklave består i vægtningen imellem disse to afgrænsningstyper. Et eksempel på hierarki (stærk gruppe og stærkt gitter) er det præstelige univers, hvor mennesker, fødevarer og ting klassificeres efter kvaliteter som hellig vs. profan, ren v. uren, afskyelig vs. normal - kvaliteter som i princippet er givne for altid. Disse afgrænsninger er vigtigere end forholdet til omverdenen, som det ses af det relativt afslappede forhold til fremmede og deres mulige rolle i kulten. Det mest oplagte gammeltestamentlige eks. på en enklave (stærk gruppe og svagt gitter) findes i Ezras og Nehemias' bøger, som vi her kan tage som eksempel på en stærkt markeret udgave af den deuteronomistiske tankegang. Her dominerer grænsen imellem gruppe og omverden, som det ses direkte i betydningen af bymuren omkring Jerusalem (hovedtema i Neh) og vagtposterne ved porten (Neh 13,19-22), og metaforisk i opløsningen af ægteskaber med ikke-israelitter (Ezra 10; Neh 13,23-29).

28. Mary Douglas, In the Wilderness, (Sheffield: JSOT. Supplement Series 1993), 42-82.

29. Som jeg her foreslår at gengive det engelske ord ved, jf. fx krystallinsk gitter; alternativer kunne være "gitterværk", "net"; "struktur" er et fór brugt ord. 
I et hierarki med dets stærke gitter er forholdet imellem individer i høj grad fastlagt: Bestemte kategorier af mennesker har en forudbestemt identitet med tilsvarende handlemuligheder. I en enklave er alle på samme niveau. Det giver forskellige "atmosfærer" og fremmer eller bremser forskellige psykologiske personligheder. I et hierarki vil der være en grad af "kølighed" i forholdet imellem individerne. Man vurderes ikke efter ens personlige kvaliteter, men efter ens plads i organisationen; megen energi vil bruges på at vogte over at individer bliver på deres plads i samfundsordenen og ikke overskrider deres kompetencer. I et hierarki er spørgsmålet om ledelse relativt klart: Her er det på forhånd fastlagt, hvem der har myndighed og kompetence til hvad. Brud på regler vil i et hierarki typisk sanktioneres ved at blive flyttet nedad i hierarkiet, evt. helt ned i bunden. I en enklave vil forholdet imellem gruppens medlemmer opleves som "varmere", nært og omsorgsfuldt. Til gengæld vil grænsen imellem gruppen og dens omverden vogtes med stor opmærksomhed. Det er afgørende vigtigt om en person er medlem af gruppen eller ej. Da den indre organisation er relativ løs, kan der dårligt sanktioneres ved at flytte en person ned i et ideelt set ikke-eksisterende hierarki; den yderste sanktion af normbrug vil derfor være at udstøde personer fra gruppen.

Ledelse er et akut problem i en enklave: da der ikke er et gitter der på forhånd fastlægger, hvem der har legitim magt, vil ledere være afhængig af at kunne etablere konsensus og at værge sig imod rivalers angreb på deres magt. Mens hierarkier ledes af personer med traditionel legitimitet, ledes enklaver typisk af personer med karismatisk legitimitet (for at bruge en velkendt sondring fra Max Weber). Af gode grunde har man foreslået at betragte Nehemias som en leder af samme type som de græske bystaters tyranner. ${ }^{30}$ Mens hierarkiets leder har sin position i kraft af en etableret orden som lederen selv ikke har bragt i stand, skyldes enklavens leders position alene dennes personlige egenskaber. Mens hierarkilederen adskiller sig fra alle andre (i kraft af den orden der har defineret den plads lederen optager), er der i enklaven ingen orden, som tilsiger, at netop lederen skal være leder. Mens hierarkilederen er synlig for alle, vil det være nærliggende for enklavelederen at underspille sin rolle som leder. Med rette betragter Mary Douglas Aron og Moses som gode eksempler på hhv. en hierarkisk og en enklavistisk leder. Mens Aron udstyres med en prægtig og kostbar dragt (Ex 28), fremhæves Moses' sagtmodighed som overgår alle andres (Num 12,3); ${ }^{31}$ tilsvarende, noget mere ver-

30. Joseph Blenkinsopp, Judaism: The First Phase (Grand Rapids, Michigan: William B. Eerdmans 2009), 113.

31. Douglas (1993), 58. 
bost, er Nehemias' forsikringer om sin asketiske levevis og ukorrupte embedsførelse (Neh 5,14-18).

I forhold til den moderate temperatur i hierarkiet vil enklaven - et begreb som ligger tæt op ad begrebet "sekt" 32 - være varm; til gengæld vil forholdet til omverdenen være på frysepunktet (normbrydere "fryses ude'). Men enklaven er også varm hvad ledelsens sæde angår, fordi det hele tiden skal beskyttes imod alternativer. Mens hierarkiets mere lunkne atmosfære derfor lægger op til lederes arrogance og urokkelighed, lægger enklavens varme op til ledernes passion og engagement. Ezra og Nehemias er gode eksempler. Begge udviser stor passion i tilfælde af kriser. Da Ezra hører om ægteskaber imellem israelitiske mænd og kvinder fra andre folk, flænger han sine klæder og sin kappe, river hår og skæg af og sidder stiv af rædsel (Ezra 9,3), og han kaster sig grædende ned foran templet, omgivet af en skare ligeledes højt grædende ligesindede $(10,1) .{ }^{33}$ Tilsvarende bliver Nehemias forbitret over hvad der betragtes som misbrug af lokaler i tempelkomplekset (Neh 13,8), og da han bliver klar over at mange børn i Jerusalem ikke taler judæisk, slår han voksne mænd og river dem $\mathrm{i}$ håret $(13,25)$.

\section{Patriarken Abraham}

Uden tvivl er præsten Ezra en anti-Aron, mens guvernøren Nehemias repeterer Moses, hvis koleriske tilbøjeligheder (Ex 32,19) kun overgås af Jahves $(32,9)$. Aron forholder sig til Moses som serænitet til passion, hvilket (kun overfladisk paradoksalt) igen svarer som ydre højhed til ydre ydmyghed. Men hvilken type er nu Abraham? Abrahams "samfund" er i første række hans husstand, dvs. ham selv, hans hustru og medhustru, hans afkom, hans trælle. Man kunne umiddelbart tro at hans type ville være hierarkilederen, eftersom en sådan "patriarkalsk"gruppe vel må antages at ledes af en "patriark" med hals-og håndsret over sin gruppes medlemmer. Men Abraham har intet af hierarkilederens visuelle statusmarkeringer og rituelle værdighed, hverken udadtil, i sin omgang med mennesker fra andre grupper, eller, måske mere overraskende, indadtil, i forhold til sin egen hus-

32. Blenkinsopp (2009), 189-193.

33. En hel monografi om Ezra-skikkelsen (Thomas Willi, Esra. Der Lehrer Israels [Leipzig: Evangelisches Verlagsanstalt 2012], 252) konkluderer at Ezra fremstilles som en søgende sjæl der udgraver Toraens potentialer (intet her om tyrannisk hysteri). De såkaldt “tankeløse fremmedægteskaber' betragtes her som en objektiv risiko for alt ægte israelitisk (s. 146). 
stand. ${ }^{34}$ Faktisk virker Abraham mest som en eksemplarisk høvding eller "big man" i et ikke-statsligt samfund, som typisk "hersker"ved at skabe situationsbestemt konsensus efter en vægtning af de relative magtforhold imellem de stridende positioner internt $\mathrm{i}$ den gruppe han leder. ${ }^{35}$ I forholdet til Sara og Hagar (Gen 16; jf. Gen 21) synes Abraham at "gå efter bogen", dvs. at give efter for førstehustruen der i kraft af en social konvention, ikke i kraft af hans suveræne beslutning, har den højeste status. At der ikke er tale om et unikt personlighedstræk ved Abraham, men om en socialkarakter, i hvert fald if. Genesis' forestillingsverden, viser fortællingerne om efterkommerne Isak og Jakob. Isak er magtesløs over sin hustru Rebekka og sine to rivaliserende sønner (Gen 27). Jakob har tilsvarende meget lidt reel myndighed i forhold til sine sønner. Han kan ikke forhindre at sønnerne Simeon og Levis forpurrer hans datter Dinas ægteskab (Gen 34), og i Joseffortællingen er han mere re- end pro-aktiv. Muligvis er patriarkfortællingerne i Genesis en god kilde til indsigt i patriarkatets egentlige væsen?

I sagens natur kan patriarkfortællingerne ikke godt være eksempel på at gruppen dominerer individet; dels er der god plads til individuelle initiativer inden for Abrahams husstand, dels er denne ingen oplagt repræsentant for en kollektiv størrelse "Israel" (som kunne organiseres i enten hierarkisk eller enklavistisk retning). Givetvis er Abraham metonymisk, som "stamfader" (i en vis forstand), forbundet med Israel. Men hans landbrugsbaserede levevis - der nok holder en fornuftig afstand til bylivet, men som ikke skyer kontakt med fastboende og etnisk fremmede - er lige atypisk i forhold til det præstelige univers' stiliserede orden omkring helligstedet og til den kollektive selvindelukkelse $i$ landet eller $i$ byen. Den religiøse stemning i Abraham-fortællingerne kan karakteriseres som en "købmands-religion" fordi kombinationen af materiel rigdom og forhandlingskompetence i forhold til etnisk fremmede virker som en ethos typisk for netop denne sociale funktion. I et sådant segment af en befolkning vil hverken en hierarkisk eller en enklavistisk grundindstilling være nærliggende. Handlende, der udveksler med mennesker fra andre kulturer, vil prioritere kendskab til andre kulturers aktuelle tilstand højere end kendskab til ens egen kulturs tidligere tilstande. I dén forstand er Abraham også et velegnet eksempel på en merkantil ethos - for ved at

34. Når Peter Sloterdijk $(2004,444)$ mener at den bibelske Jahve udviser tydelige træk af en "larmoyanten, misstraurischen, leicht aufbrausende und dekompensierende Patriarchen", kan det altså ikke være "patriarkerne" i Genesis, han har tænkt på.

35. Kirsten Hastrup \& Jan Ovesen, Etnografisk grundbog (København: Gyldendal 1985), 178. 185. 
være "den første" har han ingen fortid (der ville være værd at erindre og holde i live). Formentlig kan man antage at interessen for ens egen fortid vil være typisk for præster, mens interessen for andres nutid vil være typisk for (stor-)købmænd. ${ }^{36}$ Hvilken type viden vil da typisk være relevant for enklaven? Formentlig dens egen nutid, såsom informationer om enklavens medlemmers ret til medlemskab af enklaven, den aktuelle tilstand mht. loyalitet over for enklavens principper og sociale regler - alt sammen den type informationer og den type bekymringer der netop dominerer Ezras og Nehemias' bøger. Skriftlige arkiver af den slags, der er bevaret i disse bøger, vil være nyttig for en del af den relevante videns vedkommende; for andre dele vil naturlige informationskilder være angiveri (Ezra 9,1-2) og politiagtig overvågning (Neh 13,19).

I forhold til Gitter/Gruppe-skemaet vil rigmanden Abraham ligge til venstre på den horisontale akse individ-gruppe og altså ikke repræsentere hverken en hierarkisk eller en enklavistisk organisationsform. På den vertikale akse med sondringen imellem stærk eller svag markering af afstandene imellem individer indtager han nærmest en midterstilling. Det underliggende ideal forekommer at være isolationistisk; Abraham vil helst gerne være i fred, og han flytter hellere væk end bliver hos andre. Hans egen fortælling begynder jo med hans egen form for en exodus. På den anden side kan og må han opsøge andre, når det drejer sig om en vigtig handel, og han er endog en mester i forhandlingens kunst. I disse situationer agerer Abraham som individualist.

Denne moderat individualistisk-isolationistiske indstilling, der passer godt til en grundlæggende pacifistisk-tolerant stemning, burde egentlig ikke kunne undgå at stå som et alternativ til såvel den præstelige køligtformelle ordenstænkning som den deuteronomistisk-zelotiske aktivisme. Forskellene imellem den generelle stemning i Abraham-fortællingerne og de dominerende teologiske strømninger er indlysen-

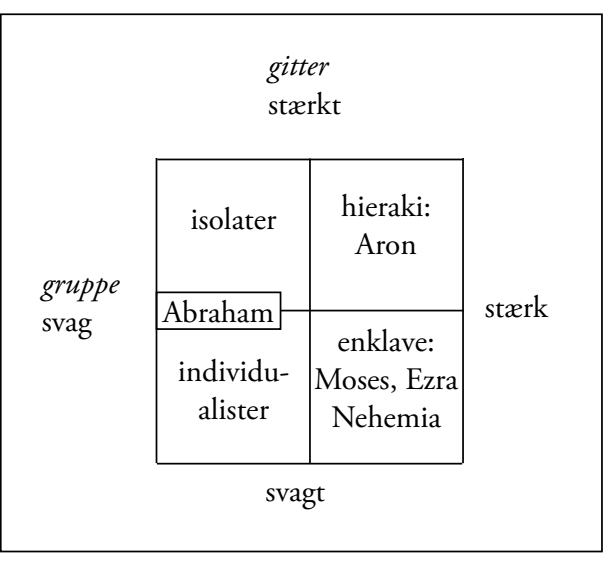

36. Som det historiske forhold imellem latin og engelsk i hhv. embeds- og handelsgymnasiet. 
de. Selvfølgelig kommer Abraham kronologisk før Sinaj og dermed i formel forstand før etableringen af de præstelige og deuteronomistiske ordener. Men dette kan ikke være forklaring nok. For disse ordener forudsætter en mangel: en præstelig mangel på en stabiliseret kult som garanti for rigdom og sikkerhed, en deuteronomistisk mangel på klare handlingsnormer som garanti for gruppeidentitet og territorial suverænitet. Abraham har ingen af delene - og mangler dem heller ikke: Han er sin egen kultleder, og han er rigeligt velsignet og beskyttet. Claus Westermann ville heri se spor af en "animistisk" "patriarktid". ${ }^{37}$ Men former fra tidligere faser findes også hvor senere faser kommer til - i dette tilfælde "de fastboendes storkult", som Westermann udtrykte det. ${ }^{38}$ Det er også mere realistisk at se kultens fravær i Abrahamfortællingerne som indikation på enten en periode i midten af det 1. årt. f.Kr. (i sen-babylonisk-tidlig-persisk tid), hvor israelitter var uden fungerende tempelkult ${ }^{39}$ eller en religiøs indstilling der kunne forekomme relevant for både generelt tempelskeptiske mennesker i og uden for Palæstina og for diaspora-baserede Jahvedyrkere i almindelighed.

Yderligere en forklaring på, at man har nedtonet Abraham-fortællingernes afstand til de mere velkendte teologiske tyngdepunkter i GT, er sikkert at der er en deuteronomiserende tendens til stede i Abrahamfortællingerne selv. Koblingen sker i og med temaet "dobbeltforjættelsen" (løftet om et stort afkom og et land til at bo i: 12,2 etc.), der gør Abraham til "Israels' stamfader og ham dermed til både årsag til og billede på den kollektivt-etnisk-nationale-religiøse størrelse Israel ("lige som Israel var allerede Abraham ...”). Westermann påpegede, jeg tror med rette, $\mathrm{i}$ en overleveringskritisk analyse at der ud over, eller rettere "nede under", dobbeltforjættelsen i Abrahamfortællingerne også var en tredje forjættelse, nemlig forjættelsen af en søn. Denne forjættelse var integreret i fortællingerne på en måde, som ikke er tilfældet med dobbeltforjættelsen (barnløshed, Ismaels fødsel, Jahves besøg i Mamre etc.); dobbeltforjættelsen burde derfor anses for en sekundær fortolkning, et stykke officiel ideologi, der ved at blive tilføjet har bøjet disse ikke-nationale fortællinger over i et nationaltetnisk univers. ${ }^{40}$ Under den etnisk-nationale Abraham kan man if.

37. Claus Westermann, Genesis 12-36 (Neukirchen-Vluyn: Neukirchener Verlag 1981), 124. - I dag vil man bedre kunne tale om "tribal” religion: Hans J. Lundager Jensen, "Robert Bellah, religion og menneskelig evolution", RVT 60 (2013), 11-31 (19-21).

38. Westermann (1981), 24 - altså arkaisk religion.

39. Lang (2002), 182f.

40. Westermann (1981), 139-144, med diskussion af tidligere forskning. Jf. Lang (2002), 185: Genesis fokuserer på en genkendelig omsorg for velsignelse og frugtbarhed (udtryk for " $[\mathrm{t}]$ he peasant and pastoralist view of good life" - ikke nogen 
Westermann endnu skimte en familie-Abraham. Jeg vil præcisere: ikke kun en pater familias, men en svag patriark, en handelsmand, en rigmand, en slaveejer.

\section{Abraham: stamfader til hvem?}

Uden her at gå ind på en nøjere analyse kan det formentlig antages at den dimension i Abraham-skikkelsen der oftest anføres i NT, er den genealogiske - Abraham som "stamfader", dvs. som emblem på jødisk identitet (fx ApG 3,13; 2 Kor 11,22; Joh 8,31-59). Over for en tilsyneladende udbredt etnisk-essentialistisk forståelse i datidens jødedom sættes gerne en mental-kognitiv forståelse, som hos Paulus: Abraham er også "fader til alle de uomskårne, som tror" og "fader til os alle" (Rom 4,11.16); "det er dem, som har troen, der er Abrahams sønner" (Gal 3,7); jf. Matt 3,9:41 "Gud kan opvække børn af Abraham af stenene dér". Argumenterne i NT for at forstå Abraham som stamfader $i$ en anden forstand end den mest "genetiske" har givetvis krævet en produktiv læsningsfantasi. Men den nytestamentlige problematik - hvem repræsenterer Abraham egentlig? - er faktisk i høj grad til stede i Genesis, som det er fremgået.

Der er en tekst i Genesis, som aktiverer netop spørgsmålet om den "genealogiske" kontinuitet: Gen 17 om pagten og omskærelsen. Dette er den "præsteskriftlige" version af den "pagt" Jahve slutter med Abraham, og som er foregrebet i Gen 15. I Gen 17 er pagt forbundet med omskærelse: "Dette er min pagt med dig og alle dine efterkommere, som I skal holde: I skal lade jeres forhud omskære ..." (v. 11). Intet her modsætter sig den forståelse af Abraham som oprindelse og ophav som “jøderne” i NT siges at have; så langt er også Gen 17 en udgave af en bøjning af en mere oprindelig Abraham-figur i en etnisk-national retning. Men kapitlet i sin nuværende litterære skikkelse komplicerer spørgsmålet. Uden tvivl er teksten det forventelige resultat af en litterær til- og omskrivningshistorie. Under alle omstændigheder er der to problemer: Hvem er egentlig Abrahams efterkommere? og: Hvordan er forholdet egentlig imellem efterkommere

penge- og handelsøkonomi her!) og afviser aristokratiske interesser i suverænitet og krig. Der er derfor en "enormous tension" imellem Genesis på den ene side - den senest tilkomne del - og resten af Hexateuken. Men i den eksisterende tekst er Genesis' egensindighed if. Lang neutraliseret ved at blive skrevet ind i en ramme domineret af de aristokratiske interesser.

41. Mogens Müller, Kommentar til Matthausevangeliet (Aarhus: Aarhus Universitetsforlag 2000), 115. 
og omskærelse? For det første lover Gud at Abraham skal blive "fader til en mængde folkeslag" (v. 5); disse må omfatte efterkommere af Ismael og uden tvivl også efter Ketura, Abrahams anden hustru (Gen 25,1-6). Kapitlet er klar over modsigelsen, for det understreges at det er Isak med hvem Gud vil oprette sin pagt (v. 19. 21), mens Ismael ("kun”) skal velsignes i overmål (v. 20). Formentlig gør man ret i her at fastholde en forlegenhed i teksten: Den har forsøgt at løse et problem, men er ikke sluppet særlig godt fra opgaven. For det andet forbindes pagten som sagt med omskærelsen. Abraham omskærer sig selv og sin søn Ismael - på trods af at pagten ikke gælder denne søn. I hvilken forstand skal omskærelsen da tages som et "pagtstegn" som det ofte kaldes i kommentarlitteraturen? Et end nu større problem består imidlertid i at det ikke kun er Abraham og Ismael der omskæres, men "alle dem, der var født i hans hus, og alle dem, han havde købt" (v. 23, jf. v. 12f. 27). Abrahams slaver er i sagens natur ikke engang sønner af huset. If. Claus Westermann ${ }^{42}$ er omskærelseskravet blevet "udvidet' til husstanden, fordi denne if. "præsteskriftet" 43 er en kultisk enhed, og at der heri ligger "en vis åbenhed" - formentlig i forhold til en strammere nationalt-etnisk tankegang. Det er som sagt korrekt at den præsteskriftlige holdning til etnisk identitet er ret afslappet. Omskårne slaver deltager i påskemåltidet (Ex 12,44), og fremmede kan deltage i kulten ved Åbenbaringsteltet (Lev 17,8). Men det kan kun forklare paradoksets fremkomst - det opløser det ikke.

Der er altså hele tre mulige svar i Gen 17 på hvem "Abrahams efterkommere" er: (1) Isak og hans efterkommere (det er formentlig denne forståelse som NT polemiserer imod); (2) Isak og Abrahams andre efterkommere: Ismael og Keturasønnerne og efterkommerne efter Esau, Abrahams sønnesøn; (3) Isak, Ismael etc. og i øvrigt alle mænd der er omskåret, uanset etnicitet. Skal uklarheden her forstås som et underforstået alternativ til en smal, enklavistisk-deuteronomistisk position? Uanset hvad er den "bemærkelsesværdigt ireniske tone" som kan fornemmes ${ }^{44}$ rigtignok til stede her; men den behøver ikke at skyldes en "præstelig" inspiration alene, for den er i samme grad i harmoni med den ligefremme visdomstradition og i øvrigt med Abraham-figuren i det hele taget.

42. Westermann (1981), 321.

43. Der menes: de narrative dele af Penteteuken der i eksegetisk tradition er benævnt 'Præsteskriftet', ikke at forveksle med de præstelige kultbestemmelser i Ex., Lev. og Num.

44. Blenkinsopp (2009), 42. 


\section{"Abraham var en hedensk mand"}

For Grundtvig var Abraham som bekendt en hedensk mand. ${ }^{45} \mathrm{Her}$ så den danske teolog alene på indholdet i Abrahams "tro". Ingen tvivl om at han var Jahve-, ikke Marduk- eller Amon-dyrker, hvad der måske for andre end Grundtvig kunne være en formildende omstændighed. Men hedenskabet har mange skikkelser. I artiklen her har jeg set på Abrahams stil: ikke på hvad han tror på, men på hans ethos, dvs. hvordan han tilrettelægger sit liv, hvordan han agerer med andre mennesker, inden for og uden for sin husstand - med andre ord: den sociologiske Abraham. Denne tilgang kan dårligt anses for relativt mindre relevant i forhold til Genesis' tekster, for det samme gør de: De er meget lidt informative om Abrahams trosforestillinger, men stærkt informative om hans handlinger og dermed, indirekte, om hans personlighed. Abraham er ikke kun den første troshelt, som den teologiske tradition vil gøre ham til, og som han allerede er blevet gjort til i Genesis' tekst. Som troshelt har han været et oplagt idol for pietistisk inspiration til alle tider. Men hvis tros-heroisme i sig selv er vigtig, hvorfor blev det så ikke Ezra eller Nehemias, der blev idoler? Også de kunne, med lidt god vilje, siges at repræsentere en slags begyndelse. Men hysteriet og skrigeriet står imod. Abraham, armslængdeprincippets helt, er derimod en identifikationsfigur til alle tider - også og ikke mindst for mennesker der ganske vist er generelt velhavende, ${ }^{46}$ men som lever $\mathrm{i}$ en så tæt og så hastig verden, dvs. så "varm", at cool er godt. Når nutidens troshelte skriger ind i TV-kameraerne, er det godt at tænke på hvordan det egl. forholder sig med "stamfaderen" til de "abrahamitiske" religioner.

45. Grundtvig, "Menneske først og Christen saa”.

46. Hvilket gælder det helt store flertal i den vestlige verden; selv de der føler sig fattige, lever i en comfort zone, der ville være utænkelig ikke kun for Abrahams trælle, men for Abraham selv. 